\title{
Evaluation of Screw Loosening on New Abutment Screws and After Successive Tightening
}

\author{
Gustavo Seabra BARBOSA ${ }^{1}$ \\ João Paulo da SILVA-NETO2 \\ Paulo Cezar SIMAMOTO-JÚNIOR ${ }^{3}$ \\ Flávio Domingues das NEVES ${ }^{2}$ \\ Maria da Gloria Chiarello de MATTOS ${ }^{4}$ \\ Ricardo Faria RIBEIRO ${ }^{4}$
}

\author{
${ }^{1}$ Department of Occlusion, Dental School, UFRN - Federal University of Rio Grande do Norte, Natal, RN, Brazil \\ ${ }^{2}$ Department of Occlusion, Fixed Prosthodontics and Dental Materials, Dental School, \\ UFU - Federal University of Uberlândia, Uberlândia, MG, Brazil \\ ${ }^{3}$ Health Technical School, UFU - Federal University of Uberlândia, Uberlândia, MG, Brazil \\ ${ }^{4}$ Department of Dental Materials and Prosthodontics, Ribeirão Preto Dental School, \\ USP - University of São Paulo,Ribeirão Preto, SP, Brazil
}

\begin{abstract}
This study evaluated the loss of the torque applied after use of new screws and after successive tightening. Four infrastructures (IE), using UCLA castable abutment type, were cast in cobalt-chromium alloy and new abutment screws (G1) were used in a first moment. Subsequently, the same abutment screws were used a second time (G2) and more than two times (G3). The values of the torques applied and detorques were measured with a digital torque wrench to obtain the values of initial tightening loss (\%). Data were analyzed by ANOVA and Tukey's test $(\alpha=0.05)$. Significant differences were observed between the G1 $(50.71 \% \pm 11.36)$ and G2 $(24.01 \% \pm 3.33)$ $(\mathrm{p}=0.000)$ and between $\mathrm{G} 1(50.71 \% \pm 11.36)$ and $\mathrm{G} 3(25.60 \% \pm 4.64)(\mathrm{p}=0.000)$. There was no significant difference between $\mathrm{G} 2$ and G3 ( $\mathrm{p}=0.774)$. Within the limitations of the study, it may be concluded that the percentage of the initial torque loss is lower when screws that already suffered the application of an initial torque were used, remaining stable after application of successive torques.
\end{abstract}

Key Words: dental implants, screws loosening, abutment.

\section{INTRODUCTION}

Screw loosening is recognized as an important complication in implant-based restorations $(1,2)$. A significant percentage of abutment/implant (A/I) assemblies present loosening on functional loading (2). An implant abutment is joined to the implant by an implant screw $(3,4)$. When the screw is tightened, a tightening torque is applied as a moment in $\mathrm{Ncm}$ to the head of the abutment screw. The applied moment is transformed along the interface of the abutment screw thread surfaces and the implant bore threaded surfaces $(3,5)$. The transformed force induces the contact force in the interface between the abutment and the implant bearing surfaces that are being clamped together. The contact force that clamps together the abutment and the implant is called the preload (4).

The component interface geometry, amount of machining tolerance provided, and component passivity can impact the potential for screw loosening (6). As the abutment screw is torqued down, preload is generated within the screw, placing the $\mathrm{A} / \mathrm{I}$ assembly under compression (7). This depends on the frictional capacity of the screw, superficial composition, metallurgical properties and torque applied (7). When torque is applied to new screws, energy is expended in smoothing surface irregularities of mating surfaces (8). It is claimed that thread friction is higher on initial closures, decreasing after repeated tightening and loosening cycles (7). The absence of passivity between components has also been shown to increase stress in the screw and results in metal fatigue failure and screw loosening (4,9-13).

Correspondence: Prof. Dr. Ricardo Faria Ribeiro, Departamento de Materiais Dentários e Prótese, Faculdade de Odontologia de Ribeirão Preto, USP, Avenida do Café, S/N, 14040-904 Ribeirão Preto, SP, Brasil. Tel: +55-16-3602-4046. Fax: +55-16-3602-4780. e-mail: rribeiro@forp.usp.br 
The stability of the A/I connection and propensity for screw loosening is also influenced by the preload. The greater the joint preload, the greater the resistance to loosening, and the more stable the joint (3).

A second variable influencing the joint stability is how the contacting parts change when the screw is tightened. After being tightened together by the screw, the micro-roughness of all the metal contacting surfaces slightly flattens and the microscopic distance between contacting surfaces decreases (6). As a result of this process called "settling" the screw loses part of its preload (9). Consequently, the clamping force that keeps the components together is also reduced. For this reason, detorque values immediately after tightening are always lower than the initial tightening torque $(7,12,13)$. Any irregularities in the matting surfaces will likely result in preload reduction because the input torque is used to flatten the rough surface rather than elongating tension in the screw to generate a clamping preload (7). Preload can be influenced by component and screw materials $(7,14)$, torque delivery systems $(15)$, manufacturer's quality control (16), screw joint design (17) surface roughness (18), and fatigue testing $(14,19)$.

Clinically, an abutment may be placed on the implant several times during the fabrication of prosthesis. Repeated tightening and loosening of uncoated abutment retaining screws has been shown to result in a progressive decay in removal torques (8). To date, little data exist on the effect of repeated tightening of abutment screws on prefabricated abutments. The purpose of this study was to evaluate the effect of screw loosening on new machined titanium abutments and after three successive tightening on the loss of the applied torque (detorque).

\section{MATERIAL AND METHODS}

This study was conducted using a brass master model simulating the curve of a human mandible with five 3.75 x $9 \mathrm{~mm}$ external hex implants (Titamax; Neodent, Curitiba, PR, Brazil) with regular platform (4.1 $\mathrm{mm}$ ). For these implants, castable abutments (UCLA; Neodent) were tightened with a $20 \mathrm{Ncm}$ torque using a hand-wrench as recommended by the manufacturer.

Impression of the system was made using a custom tray and polyether-based impression material (Impregum Soft; 3M/ESPE, Seefeld, Germany). After setting of the material, the molds were removed and titanium external hex implant analogues ( $4.1 \mathrm{~mm}$; Neodent) were adapted to the transfers. Type IV dental stone (Durone IV;
Dentsply Ind. e Com. Ltda., Petrópolis, RJ, Brazil) was poured into the molds and master casts were obtained.

UCLA castable abutments were positioned on the master casts. Five-millimeter diameter sticks were cut and positioned between the abutments and at the free ends, forming a $10-\mathrm{mm}$ cantilever. The implants were identified by sequential letters, being ' $A$ ' and ' $E$ ' the distal implants. Four frameworks were fabricated with a silicon matrix (Silon 2 APS; Dentsply Ind. e Com. Ltda.) reproducing the initial wax pattern. A passive fit test of the waxed frameworks was done by manually tightening screw at one end and assessing the fit at the other end. If misfits were observed, the wax sticks were cut and joined again with melted wax to correct the inaccuracies.

The frameworks were invested with phosphate based investment (Castorit Super C; Dentaurum, Ispringen, Germany), and the rings were burned out in an oven (EDG 3000 10P; EDG Equipments and Controls Ltd., São Carlos, SP, Brazil), following the recommended thermal cycle and the casting temperature was approximately $950^{\circ} \mathrm{C}$ for $\mathrm{Co}-\mathrm{Cr}$ alloy (Remanium 2000; Dentaurum), according to the manufacturer's instructions. The one-piece casting process was performed in a Discovery plasma machine (EDG Equipments and Controls Ltd.), which produces an electric arc melting in a vacuum and argon-inert atmosphere, with injection of the alloy into the mold by vacuum pressure. All process runs automatically. After casting, the frameworks were divested and sandblasted with $100-\mu \mathrm{m}$ particle aluminum oxide $(80 \mathrm{psi}=5.62$ $\mathrm{kgf} / \mathrm{cm}^{2}$ ), avoiding damage to the seating regions of the prosthetic cylinders. Sprue formers and small nodules were carefully removed under magnification. No further finishing or polishing procedures were performed to ensure uniformity of the frameworks.

The frameworks were installed with a torque of $20 \mathrm{Ncm}$ using a digital wrench (TQ-680; Instrutherm Measurement Instruments, São Paulo, SP, Brazil) following a specific order (abutment screw ' $\mathrm{C}$ ' was screwed first followed by abutment screws 'A', 'E', 'B' and ' $D$ '). This sequence was used in order to reduce the tension generated in the infrastructure when the squeeze started in the distal implants, and also to standardize the sequence of tightening or loosening. New screws were used to all frameworks for initial analyses. The screws remained tight for a period of $10 \mathrm{~min}$, in order to standardize the tightening time for all groups. After that time, they would suffer the loosening.

The digital wrench (TQ-680) was also used to 
evaluate torque loss in the abutment screws. With the framework installed over the metallic matrix, the set was positioned in a paralelometer and the key installed in the digital torque wrench to measure the detorque value. The matrix was turned to loosen the screw and the digital torque wrench was used to measure the detorque values. This procedure was performed in all framework screws following the same order ('C', 'A', 'E', 'B' and 'D'), totalizing 20 values.

Group G1 was composed of the new screws, which had not yet been used. After the first sequence of tightening and loosening, the same screws were used again and a new sequence of tightening and loosening was performed, thus forming group G2 group. Later, the screws were subjected to other two tightening and loosening sequences, forming group G3. To obtain the values of tightening loss related to the initial torque, a basic arithmetic reason between the initial torque, which correspond to $100 \%$ of the tightening value (20 $\mathrm{Ncm}$ ), and the value of the torque loss (X) related to the initial torque value in the detorque process (D), with the following equation: " $20 * X \backslash 20-\mathrm{D} * 100$ ".

The screws, new and used, were analyzed with a scanning electron microscope (LEO 435 VP microscope, LEO Electron Microscopy Ltd., Cambridge UK) at 20 $\mathrm{kV}$, high vacuum mode, under $260 \times$ magnification

Data were collected and analyzed by ANOVA and Tukey's test using the SPSS 12.0 statistical software package (SPSS Inc., Chicago, IL, USA). A significance level of $5 \%$ was set for all analyses.

\section{RESULTS}

There were significant differences between G1 $(50.71 \% \pm 11.36)$ and $\mathrm{G} 2(24.01 \% \pm 3.33)(\mathrm{p}=0.000)$ and between G1 $(50.71 \% \pm 11.36)$ and G3 $(25.60 \% \pm$ 4.64) $(\mathrm{p}=0.000)$. No significant difference was observed between $\mathrm{G} 2$ and $\mathrm{G} 3(\mathrm{p}=0.774)$.

Table 1 presents the loosening torque (\%) per implant, expressed as means and standard deviations. Figures 1 and 2 show SEM micrographs of a screw before and after tightening, respectively.

Table 1. Loosening torque (\%) per implant, mean and standard deviation.

\begin{tabular}{lccccc}
\hline & \multicolumn{5}{c}{ Implants } \\
\cline { 2 - 6 } Groups & $\mathrm{A}$ & $\mathrm{B}$ & $\mathrm{C}$ & $\mathrm{D}$ & $\mathrm{E}$ \\
\hline $\mathrm{nyyyyy}$ G2 & $56.5(2.48)^{\mathrm{A}}$ & $56.5(11.29)^{\mathrm{A}}$ & $40.1(17.16)^{\mathrm{A}}$ & $54.22(4.26)^{\mathrm{A}}$ & $46.22(9.49)^{\mathrm{A}}$ \\
G3 & $26.12(3.93)^{\mathrm{B}}$ & $25.3(2.39)^{\mathrm{B}}$ & $24.9(3.82)^{\mathrm{B}}$ & $23.75(3.54)^{\mathrm{B}}$ & $23.8(3.99)^{\mathrm{B}}$ \\
& $27.82(4.68)^{\mathrm{B}}$ & $28.57(6.20)^{\mathrm{B}}$ & $26.42(3.22)^{\mathrm{B}}$ & $22.95(3.81)^{\mathrm{B}}$ & $22.2(2.58)^{\mathrm{B}}$ \\
\hline
\end{tabular}

Different letters indicate statistically significant difference $(\mathrm{p}<0.05)$.

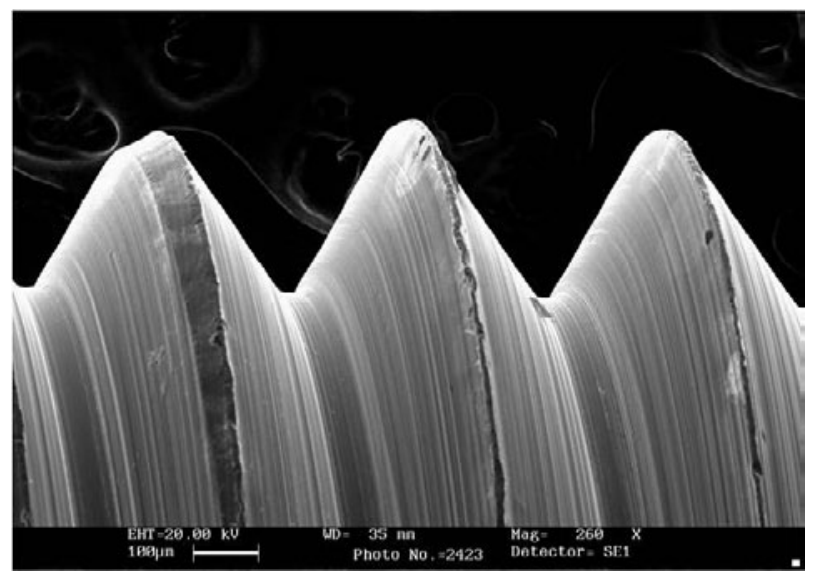

Figure 1. Screw before tightening.

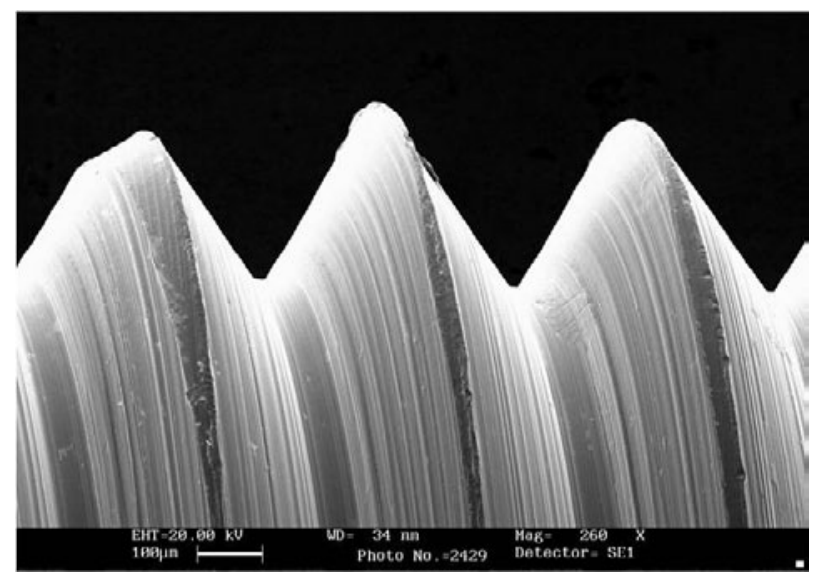

Figure 2. Screw after tightening. 


\section{DISCUSSION}

In all groups, high torque loss was obtained in the first loosening (detorque), whereas in the second and third, the losses were lower. Detorque values for all groups were lower than the initial tightening torque, and ranged from 24.01 to $50.71 \%$ of the initial tightening torque. These results are consistent with findings that showed the retaining evaluated detorque values in external hexagonal titanium abutments stands about $83.3 \%$ prior to loading $(7,12,13,18)$.

Thread friction decreases with repeated closing and opening, and this process is assumed to cause changes in opening torsional failure on consecutive closing and opening cycles (7). Coefficient of friction is controlled by the manufacturing process and is affected by metallurgical properties of the components, design, and quality of the surface finish. The presence and quantity of lubricant (saliva, periimplant fluid, and/ or blood) between the implant's mating components, which is clinically unpredictable, can also affect the coefficient of friction (8). Investigators have suggested that repeated tightening of screws removes small irregularities on the mating surfaces, which in turn reduces the friction at the surface and leads to higher preload $(3,7,13,18)$. This sign was proven by the SEM analysis, which showed removal of the screws spirals irregularities after successive torques (Figs. 1 and 2). Such event could explain why the values of detorque increased after the second detorque, and the samples remained constant in the subsequent detorques in all body tests. The removal of the surface irregularities must allow less friction between the screw surface and the internal implant surface, favoring the screw sliding and a higher preload transmission.

Weiss et al. (8) performed up to two hundred closures of implant abutment screws and demonstrated that the opening torque values decreased progressively. Though preload was not measured in Weiss's study, these results are consistent with the reduction of friction model outlined above and with the reduced coefficient of friction measured by Haack et al. (7). Indeed, Tzenakis et al. (20) found that the preload in gold alloy prosthetic screws increased after 5 or 10 tightening procedures. Moreover, studies have shown that when a lower torque is applied over titanium alloy screws, about $10 \mathrm{Ncm}$, these screws present values of daily preload approximately $10 \%$ higher when compared to gold alloy screw with the same torque (3). This study demonstrated that after successive tightening procedures, titanium alloy screws of machined abutments presented constant detorque values even when different torque values were applied $(3,13)$. Such results may lead to the assumption that successive tightening of titanium alloy screws does not influence the loss of the daily preload when used in the same implant. Therefore, in the first cycle of tightening and loosening, the torque applied is lost in a significant amount by the process of friction of the screw surfaces with the internal implant surfaces.

Data showing that from the second opening/ closing cycles forward the values of detorque become constant do not exist. Based on the results of this work, it appears that when new screws were used for the final installation of multiple implant-supported prostheses, the torque loss observed at first detorque cycle is higher. Nevertheless, further studies should be carried out to elucidate these questions. It is therefore advisable that torque/detorque cycles be minimized both in laboratory and clinical routines in order to reduce the chances of any torque loss after the final abutment positioning.

Within the limitations of this study, the following conclusions may be drawn: loosening percentage of the initial torque is smaller when using screws that already suffered application of an initial torque, staying stable after successive tightening procedures.

\section{RESUMO}

O objetivo deste estudo foi avaliar a perda do torque inicial, quando usados novos parafusos de pilares e após sucessivos apertos. Quatro infra-estruturas (IE), utilizando pilares calcináveis tipo UCLA, foram fundidas em liga de cobalto-cromo, onde novos parafusos de pilares foram utilizados $(\mathrm{G} 1)$ em um primeiro momento. Posteriormente os mesmos parafusos de pilares foram utilizados em um segundo momento (G2), e depois por mais duas vezes (G3). Os valores de torque e detorque aplicados foram mensurados a partir de um torquímetro digital para obtenção dos valores de perda do torque inicial (\%). Os dados foram coletados e submetidos à análise de variância e teste de Tukey $(\mathrm{p}<0,05)$. Foram observadas diferenças estatisticamente significantes entre os grupos G1 $(50,71 \% \pm 11,36)$ and $G 2(24,01 \% \pm 3,33)(p=0,000)$ and the groups G1 $(50,71 \% \pm 11,36)$ and G3 $(25,60 \% \pm 4,64)$ $(p=0,000)$. Os maiores valores foram encontrados para o grupo G1. Não houve diferença estaticamente significante entre os grupos G2 e G3 ( $p=0,774)$. Dentro das limitações deste estudo, pôde-se observar que a porcentagem de perda de torque inicial foi menor quando os parafusos já haviam sofrido a aplicação do primeiro torque, se mantendo estáveis após os demais torques.

\section{ACKNOWLEDGEMENTS}

This research was supported by CNPq (Grant \#305480/2004-9). 
The components used in this study were provided by Neodent, Curitiba, PR, Brazil. The authors would like to thank Prof. Dr. Elliot Watanabe Kitajima (NAP/MEPA - ESALQ-USP) for his assistance and permission to use the LEO 435 VP microscope.

\section{REFERENCES}

1. Wolfinger GJ. Implant prosthodontic and restorative complications. Int J Oral Maxillofac Implants 2003;18:766-767.

2. Goodacre CJ, Bernal G, Rungcharassaeng K, Kan JY. Clinical complications with implants and implant prostheses. J Prosthet Dent 2003;90:121-132.

3. Byrne D, Jacobs S, O'Connell B, Houston F, Claffey N. Preloads generated with repeated tightening in three types of screws used in dental implant assemblies. J Prosthodont 2006;15:164-171.

4. Patterson EA, Johns RB. Theoretical analysis of the fatigue life of fixture screws in osseointegrated dental implants. Int J Oral Maxillofac Implants 1992;7:26-33.

5. Lang LA, Kang B, Wang RF, Lang BR. Finite element analysis to determine implant preload. J Prosthet Dent 2003;90:539-546.

6. Kano SC, Binon P, Bonfante G, Curtis DA. Effect of casting procedures on screw loosening in UCLA-type abutments. J Prosthodont 2006;15:77-81.

7. Haack JE, Sakaguchi RL, Sun T, Coffey JP. Elongation and preload stress in dental implant abutment screws. J Oral Maxillofac Implants 1995; 10:529-535.

8. Weiss EI, Kozak D, Gross MD. Effect of repeated closures on opening torque values in seven abutment-implant systems. J Prosthet Dent 2000;84:194-199.

9. Binon PP. The external hexagonal interface and screwjoint stability: a primer on threaded fasteners in implant dentistry. Quintessence Dent Technol 2000;91-105.

10. Taylor TD, Agar JR, Vogiatzi T. Implant prosthodontics: current perspective and future directions. Int J Oral Maxillofac Implants 2000;15:66-75
11. Barbosa GA, Simamoto Júnior PC, Fernandes Neto AJ, de Mattos Mda G, Neves FD. Prosthetic laboratory influence on the vertical misfit at the implant/UCLA abutment interface. Braz Dent J 2007;18:139-143.

12. Barbosa GA, Bernardes SR, das Neves FD, Fernandes Neto AJ, de Mattos Mda G, Ribeiro RF. Relation between implant/abutment vertical misfit and torque loss of abutment screws. Braz Dent J 2008; 19:358-363.

13. Spazzin AO, Henrique GE, Nóbilo MA, Consani RL, CorrerSobrinho L, Mesquita MF. Effect of retorque on loosening torque of prosthetic screws under two levels of fit of implant-supported dentures. Braz Dent J 2010;21:12-17.

14. Martin WC, Woody RD, Miller BH, Miller AW. Implant abutment screw rotation and preload for four different screw materials and surfaces. J Prosthet Dent 2001;86:24-32.

15. Tan KB, Nicholls JI. The effect of 3 torque delivery systems on gold screw preload at the gold cylinder-abutment screw joint. Int J Oral Maxillofac Implants 2002;17:175-183.

16. Tan KB, Nicholls JI. Implant-abutment screw joint preload of 7 hex-top abutment systems. Int $J$ Oral Maxillofac Implants 2001;16:367-377.

17. Schulte JK, Coffey J. Comparison of screw retention of nine abutment systems: a pilot study. Implant Dent 1997;6:28-31.

18. Carr AB, Brunski JB, Hurley E. Effects of fabrication, finishing, and polishing procedures on preload in prostheses using conventional 'gold' and plastic cylinders. Int J Oral Maxillofac Implants 1996;11:589-598

19. Cibirka RM, Nelson SK, Lang BR, Rueggeberg FA. Examination of the implant-abutment interface after fatigue testing. J Prosthet Dent 2001;85:268-275.

20. Tzenakis GK, Nagy WW, Fournelle RA, Dhuru VB. The effect of repeated torque and salivary contamination on the preload of slotted gold implant prosthetic screws. J Prosthet Dent 2002;88:183-191.

Accepted December 21, 2010 